\title{
残留オーステナイトを含む 複合組織鋼板の変形と変態過程
}

\author{
鄭 鎭煥*・張 栄遠*2
}

Deformation and Transformation Processes of a Multi-phase Sheet Steel Containing Retained Austenite Jin Hwan Chung and Young Won CHAng

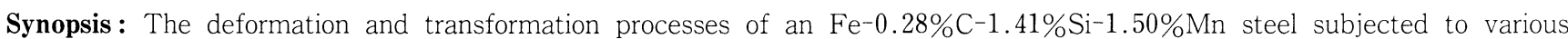
annealing conditions were investigated using in-situ TEM and SEM straining techniques. The retained austenite $\left(\gamma_{\mathrm{R}}\right)$ was observed in three distinctly different morphological forms, i. e., a film type located between bainite laths, an island type isolated in relatively large ferrite grains, and a granular type located at grain boundaries especially triple junction points. When stress was applied on the steel, the ferrite matrix was found to deform first piling-up dislocations at ferrite $-\gamma_{\mathrm{R}}$ boundaries. The internal stress fields generated by these piled-up dislocations seem to act as the driving force for the deformation induced transformation of $\gamma_{\mathrm{R}}$. As the plastic deformation proceeded, fracture began with void formation at ferrite-second phase interfaces leading into subsequent void growth and coalescence until a final failure. The in-situ TEM observation showed that the transformation of $\gamma_{R}$ is accomplished in the two different paths, i. e., $\gamma_{R}$ $\rightarrow$ twin $\rightarrow \alpha^{\prime}$ and $\gamma_{R} \rightarrow \alpha^{\prime}$. The orientation change resulting from a $\gamma_{R} \rightarrow \alpha^{\prime}$ transformation can be described by the Kurdjumov-Sachs relationship.

Key words : multi-phase steel ; annealing ; deformation induced transformation ; retained austenite ; transformation induced plasticity; deformation process.

\section{1. 諸言}

近年，高強度鋼板の延性向上を目的として，残留オース テナイト $\left(\gamma_{\mathrm{R}}\right)$ を含む新しいタイプの複合組織鋼板の研究が 盛んに行われている(1) 3)。この種の鋼板は変形中に鋼中の $\gamma_{R}$ の変態誘起塑性(Transformation Induced Plasticity: TRIP) 効果 ${ }^{4)}$ により強度〜延性バランスが従来の高強度鋼板 に比べて著しく優れる特徴がある。この鋼板の機械的性質 は $\gamma_{\mathrm{R}}$ の体積率, 分布状態, 寸法および安定度などの組織因 子に大きく影響されるので，より多くてなおかつ安定度の 高い $\gamma_{\mathrm{R}}$ 鋼中に分布させるような合金設計や熱処理方法の 工夫に関する研究が数多くなされてきた1) 315) 7)。

$\gamma_{\mathrm{R}}$ 含有鋼の延性向上機構としては $\gamma_{\mathrm{R}}$ の加工誘起変態によ る高い加工硬化率 $(\mathrm{d} \sigma / \mathrm{d} \varepsilon)$ に起因し, $\mathrm{d} \sigma / \mathrm{d} \varepsilon$ の増加がネッキ ングを抑制して均一伸びを増加させることが認められてい る。またTRIP効果を有効に発揮させ高い延性を得るために は変形中にマルテンサイトに変態する $\gamma_{\mathrm{R}}$ の量のみならず変 態時期も重要であり，ひずみの増加とともに次第に変態が 起こる必要がある。Goel $5^{8) 9}$ は $\gamma_{\mathrm{R}}$ 量の異なる複合組織鋼板
を用いた变形挙動の理論計算で变態時期(主に $\gamma_{\mathrm{R}}$ の安定度に 依存する) が鋼板の延性を大きく支配すること導いた。彼 らは鋼中に含まれている $\gamma_{\mathrm{R}}$ が加工誘起変態を起こす前には 母相のフェライトと同様に伸びるという仮定を用いた。杉 本ら ${ }^{10)}$ も加工誘起変態に先んじて $\gamma_{\mathrm{R}}$ の塑性変形が生ずること を報告したが， $\gamma_{\mathrm{R}}$ の変形に関する直接的な実験証拠は提示 されていない。

一方, 加工誘起マルテンサイトの変態過程についてはス テンレス鋼や高合金鋼のようなオーステナイト単相組織鋼

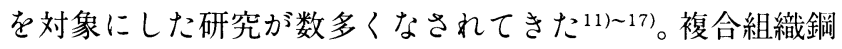
板の変態過程については, dual phase鋼板に少量含まれて いる $\gamma_{\mathrm{R}}$ の変態に関するB.V.N.Rao ${ }^{18)}$ の研究があるだけで, 比較的多量の $\gamma_{\mathrm{R}}$ を含むTRIP型鋼板を対象にした研究は見当 らない。

本研究では, 二相域焼鈍と恒温変態処理との組合わせで 鋼中の $\gamma_{\mathrm{R}}$ 量を変化させた試料を用いて, 引張変形中の各相 の変形挙動と $\gamma_{\mathrm{R}}$ の変態過程について電子顕微鏡のその場観 察により微細組織的検討を行った。 


\section{2. 実験方法}

試料は真空溶解法により作製した $0.28 \% \mathrm{C}-1.41 \% \mathrm{Si}-$ $1.50 \% \mathrm{Mn}$ 鋼 (wt.\%) t用いた。Fig. 1 に示すように溶解した 試料は熱間鍛造により $30 \mathrm{~mm}$ 厚のスラブにした後 $1250^{\circ} \mathrm{C} て ゙ 1$ 時間加熱後 3 パースの熱間圧延で $4.0 \mathrm{~mm}$ 厚の板とした。そ の後70\%の冷間圧延を施し $810^{\circ} \mathrm{Cにて} 5 \mathrm{~min}$ 加熱後種々の温 度でベイナイト变態処理を施した。

$\gamma_{\mathrm{R}}$ の測定はX-線回折装置を用いてMo-K $\alpha$ の特性X-線で 行い, $\gamma_{R}$ 量 $\left(V_{R}\right)$ は次式より求めた ${ }^{19) 20) 。 ~}$

$$
\mathrm{V}_{\mathrm{R}}=1.4 \mathrm{I} \gamma /(\mathrm{I} \alpha+1.4 \mathrm{I} \gamma)
$$

ここでI $\gamma$ はオーステナイトの (220) $\gamma$ および(311) $\gamma$ 面からの 積分反射強度の平均值であり, $\mathrm{I} \alpha$ はフェライトの (211) $\alpha$ 面 からの積分反射強度值である。

引張試験はインストロン型引張試験機を用い, 室温, ひ ずみ速度 $3.33 \times 10^{-3} / \mathrm{s} て ゙$ 行った。

試料の微細組織は走査型電子顕微鏡 $(\mathrm{SEM})$ および透過型

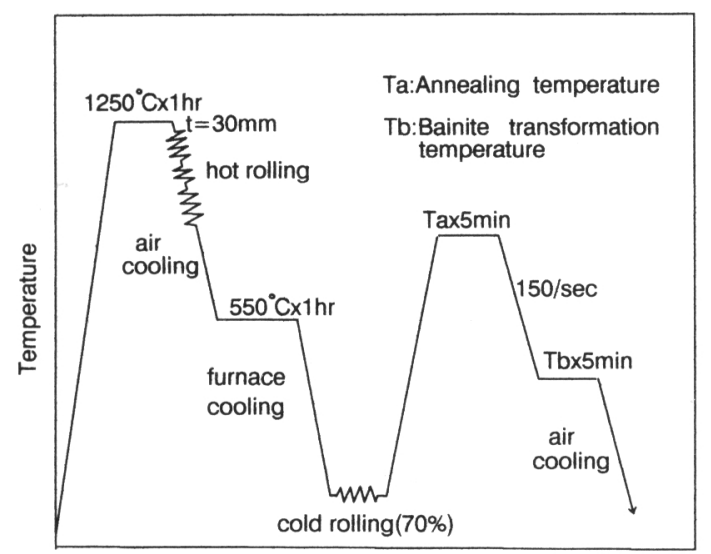

Fig.1.Schematic illustration of specimen preparation.

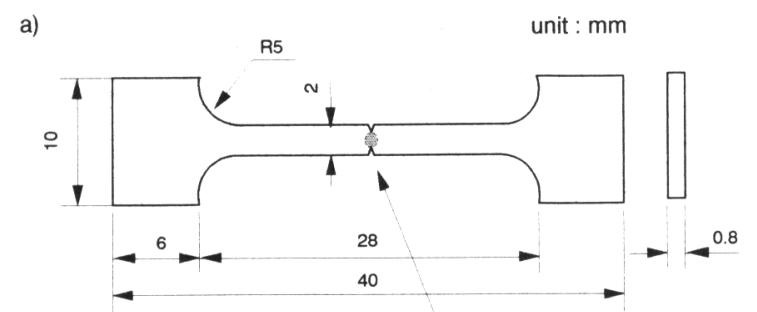

b)

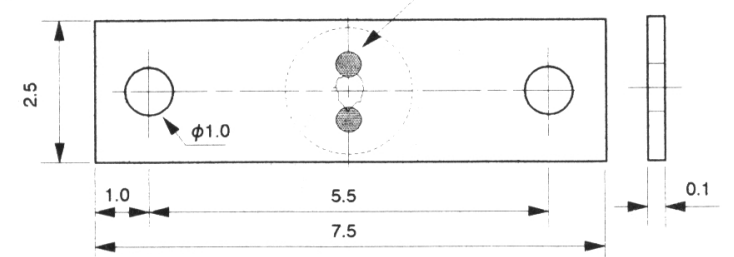

Fig.2.Configurations of (a) in-situ SEM and (b) insitu TEM straining specimen.
電子顕微鏡 $(\mathrm{TEM}: \mathrm{JEM} 200 \mathrm{CX}) に よ り$ 観察し, 変形および 変態過程は電子顕微鏡のその場観察を行った。Fig. 2 に電顕 その場観察用試験片の形状と寸法を示した。SEMその場観 察用試験片は表面から 1/4厚まで研磨した後ナイタルエッチ ングで作成し, TEMその場観察用試験片は放電加工により Fig. 2 (b) に示す寸法にした後, 機械研磨および電解研磨で 作成した。研磨液は酢酸と過塩素酸の体積比が $9 ： 1 の$ 混 合液を使用した。

\section{3. 実験結果および考察}

\section{$3 \cdot 1$ 初期組織と機械的性質}

鋼板の構成組織を変化させるため, $810^{\circ} \mathrm{C} て ゙ 5 \mathrm{~min}$ 加熱後 種々の温度にて $5 \mathrm{~min} の$ 恒温变態処理を施した。

Fig. 3 は恒温変態処理温度の異なる試料の断面組織であ る。写真で黒色はフェライトを, 白色は第 2 相 $\left(\gamma_{R}\right.$, ベイナ イトおよびパーライトの単相あるいは混合組織) を表す。変 態温度の低いT 2 鋼では針状の第 2 相が多く分布しているが, 温度の上昇とともに針状組織は少なくなり T 5 鋼では多量の 第 2 相が層状のパーライトに変態することがわかる。

Table 1 に恒温変態処理温度の異なる試料についてX-線 回折法で測定した $\gamma_{\mathrm{R}}$ 量と引張試験により得た機械的性質を 示す。 $\gamma_{\mathrm{R}}$ 量は変態処理温度によってかなり異なり，鋼板の 機械的性質は構成組織の影響を直接に受けている。すなわ ち二相域焼鈍後に焼入れしたT 1 鋼は強度が極めて高いのに 対し伸びが低く, 恒温変態処理温度の高いT 5 鋼は強度と伸 び両方とも低いが，T 2 〜 T 4 鋼は強度〜延性バランス(引 張強度×延伸率) が相対的に優れている。このような結果は 熱処理材の構成組織から十分予想できる。すなわち $\mathrm{T} 1$ 鋼は 極少量の $\gamma_{\mathrm{R}}$ を含むdual phase鋼であり, T 5 鋼は $\gamma_{\mathrm{R}}$ が $12 \%$ と 比較的少なくパーライトが多量に含まれている組織となる ためである。それに対してT 2 T T 鋼は $\gamma_{\mathrm{R}}$ 量が多くて強度

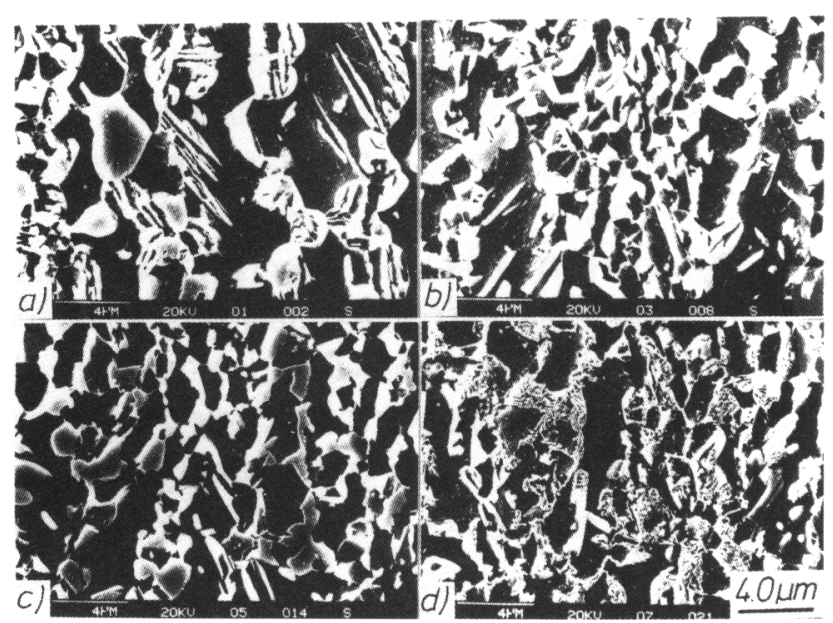

Fig.3.Scanning electron micrographs showing microstructural change with isothermal transformation temperature; (a) T2, (b) T3, (c) T4, and (d) T5. 
Table 1. Mechanical properties and microstructures of the specimens.

\begin{tabular}{c|c|c|c|c|c|c|c}
\hline steel & $\begin{array}{c}\text { transformation } \\
\text { temperature } \\
\left({ }^{\circ} \mathrm{C}\right)\end{array}$ & $\begin{array}{c}\text { amount } \\
\text { of } \gamma_{\mathrm{R}} \\
(\%)\end{array}$ & $\begin{array}{c}\text { yield } \\
\text { strength } \\
(\mathrm{MPa})\end{array}$ & $\begin{array}{c}\text { tensile } \\
\text { strength } \\
(\mathrm{MPa})\end{array}$ & $\begin{array}{c}\text { total } \\
\text { elongation } \\
(\%)\end{array}$ & $\begin{array}{c}\text { tensile strength } \\
\times \text { elongation } \\
(\mathrm{MPa} \cdot \%)\end{array}$ & $\begin{array}{c}{ }^{*} \text { micro- } \\
\text { structures }\end{array}$ \\
\hline T1 & W.Q & - & 394 & 1407 & 9.7 & 13648 & $\alpha+\alpha$ \\
T2 & 350 & 10.9 & 413 & 1036 & 20.5 & 21238 & $\alpha+\mathrm{B}+\gamma_{\mathrm{R}}$ \\
T3 & 400 & 24.1 & 505 & 874 & 34.6 & 30240 & $\alpha+\mathrm{B}+\gamma_{\mathrm{R}}$ \\
T4 & 450 & 29.0 & 458 & 950 & 28.3 & 26885 & $\alpha+\mathrm{B}+\gamma_{\mathrm{R}}$ \\
T5 & 500 & 12.1 & 462 & 948 & 13.1 & 12419 & $\alpha+\mathrm{B}+\gamma_{\mathrm{R}}+\mathrm{P}$ \\
\hline
\end{tabular}

$* \alpha$ : ferrite, $\alpha^{\prime}$ : martensite, $\gamma_{\mathrm{R}}$ : retained anstenite

$\mathrm{B}$ : bainite, $\mathrm{P}$ : pearlite

〜延性バランスも優れているが， $\gamma_{\mathrm{R}}$ の量と強度〜延性バラ ンスがかならずしも比例するのではない。 $\gamma_{\mathrm{R}}$ 量の最も多い $\mathrm{T} 4$ 鋼 $\left(\gamma_{\mathrm{R}}=29 \%\right)$ がT 3 鋼 $\left(\gamma_{\mathrm{R}}=24 \%\right)$ よりも強度 $\times$ 延性の 值と伸びが低い。このような結果はこの種の鋼板の機械的 性質が $\gamma_{\mathrm{R}}$ の量のみならず分布状態，寸法および安定度等に も依存する ${ }^{6) 7)}$ こ走唆している。

\section{$3 \cdot 2 \gamma_{\mathrm{R}}$ 含有鋼の変形過程}

$\gamma_{\mathrm{R}}$ を含む複合組織鋼板の変形と破壊過程を調べるため,

Fig. 2 に示した電顕その場変形試験片を用いて変形途中の組 織観察を行った。

実験鋼で観察される代表的な $\gamma_{\mathrm{R}}$ の形態はFig. 4 に示すよう に三つのタイプに分けることができ，次のような特徴があ る。

(1) フィルム状 (Film type): ベイナイト又はマルテンサ イトのラス間に細長く存在する $\gamma_{\mathrm{R}}$

(2) 島状 (Island type): 比較的大きいフェライト結晶粒内

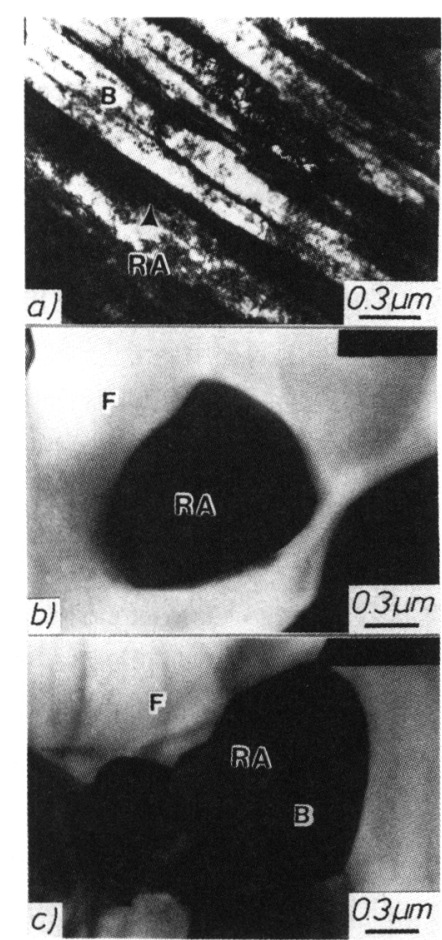

Fig.4.Transmission electron micrographs showing three types of retained austenite; (a)film type, (b) island type, and (c) granular type.
に単独で孤立して存在する $1 \mu \mathrm{m}$ 以下の小さい $\gamma_{\mathrm{R}}$

（３）塊状 (Granular type)：フェライト結晶粒界, 特に三 重点に沿って存在する $2 \mu \mathrm{m}$ 前後の $\gamma_{\mathrm{R}}$

この三つのタイプについて初期変形過程をTEMその場観 察を行った。フィルム状の变形過程はTEMでは観察できな かった。このタイプの $\gamma_{\mathrm{R}}$ は硬質第 2 相によって変形が拘束 されるため7), 低ひずみ域では変形し難く, 後述するように 高ひずみ域で変形することが確認された(Fig. 7$) 。$

Fig. 5 は島状の $\gamma_{\mathrm{R}}$ を含むフェライト結晶粒の初期変形過程 を示す。フェライト結晶粒の変形と同時に $\gamma_{\mathrm{R}}$ 粒の周りに転 位のループが形成されているが， $\gamma_{\mathrm{R}}$ 粒自身の変形や変態は 起こらなかった。寸法の小さいこのタイプの $\gamma_{\mathrm{R}}$ は焼鈍前に フェライト粒内に存在する炭化物を中心に形成されたオー ステナイトが恒温変態処理時に安定化したもので6), 外力を

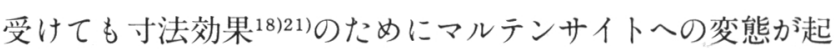
こり難く, 鋼中では析出物と同様な役割をすると考えられ る。

Fig. 6 は塊状の $\gamma_{\mathrm{R}}$ を含む試料の初期変形過程を示す。変形 前の初期状態 (Fig. 6 ( a ))の試料ではべイナイト変態時に生 じた転位が存在している。それに応力を加えるとフェライ 卜粒がすべり変形を起こしながら $\gamma_{\mathrm{R}}$ との境界に転位が堆積 することがわかる(Fig. 6 (b)，（c））。

以上のTEMその場変形実験は薄膜試料に限られる制限が あり，また薄膜試料の作製時に各相間の厚みの差が生じて 薄い相が優先的に変形する可能性もある。そこで本実験で はバルク試料のマクロ的な変形過程を確認するため, SEM その場変形実験を行った。

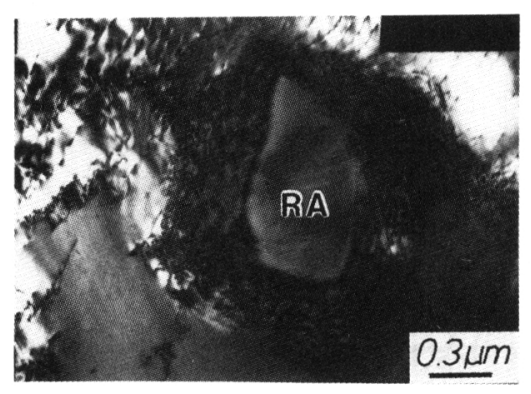

Fig.5.Transmission electron micrograph during insitu straining of an island type of retained austenite. 


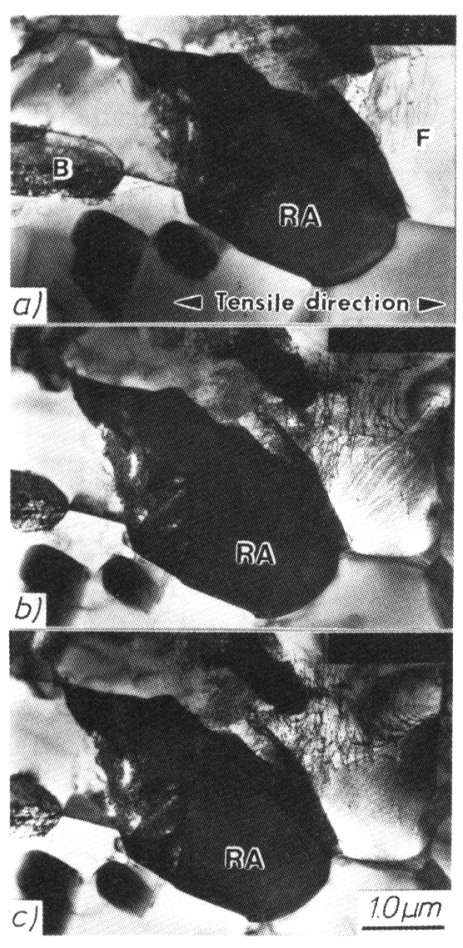

Fig.6.In-situ transmission electron micrographs showing three successive stages of straining for a granular type of retained austenite.

Fig. 7 はT 3 鋼の変形と破壊過程をSEM との場変形実験 で観察した一連の写真である。Fig. 7 ( a ) は変形前の試料状 態を示し, Fig. 4 で述べた三つのタイプの $\gamma_{\mathrm{R}}$ を含んでいる。 写真中の $\mathrm{A}$ は島状の $\gamma_{\mathrm{R}}$ 含むフェライト結晶粒を，Bはフ イルム状の $\gamma_{\mathrm{R}}$ t, C は塊状の $\gamma_{\mathrm{R}}$ t表す。変形の初期段階 (Fig. 7 (b ))ではフェライト結晶粒内にすべり線の筋が見られ, フェライト結晶粒 A も $10 \%$ 程度伸びているが， $\gamma_{\mathrm{R}}$ の変形は 認められない。 $\gamma_{R}$ の形態別の変化を見ると，A粒中の島状 とCの塊状㗞断直前 (Fig. 7 (d)) までほとんど変形しない ことがわかる。一方，フィルム状の $\gamma_{\mathrm{R}}($ 写真中のB) は変形 量の増加に伴って引張方向へ向って回転し, 変形末期では 大きく伸びている。

Fig. 8 は引張試験で破断した試料のネッキング部の断面組 織である。フェライトと第 2 相の境界でボイドが見られ， 第 2 相は引張方向と平行に配向することがわかる。この結 果はFig. 7 のSEMその場観察結果とよく一致するもので, この種の鋼板の破壊はdual phase鋼板の破壊挙動 ${ }^{2223)}$ と同様 にフェライトと第 2 相との界面から生成したボイドが成長 して破断に至ると考えられる。

以上のTEMによるミクロ的観察とSEMによるマクロ的観 察結果から， $\gamma_{\mathrm{R}}$ 含さ複合組織鋼板の変形は次のような過 程を経ると考えられる。フエライト，ベイナイトおよび $\gamma_{\mathrm{R}}$ から構成される試料に引張応力を加えるとまずべイナイト 変態時に生じた転位が隣のフェライト粒内で動き始める。 続いて変形を進めると $\gamma_{\mathrm{R}}$ の周りに転位が堆積されることに より内部ひずみエネルギーが生じて変態に必要な駆動力に

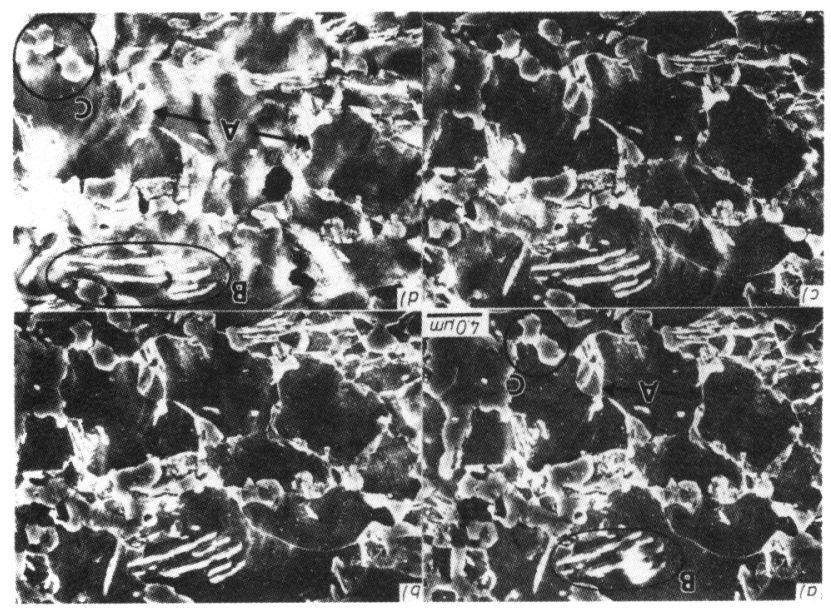

Fig.7.In-situ scanning electron micrographs showing four successive stages of straining. Tensile direction is horizontal to the micrograph.

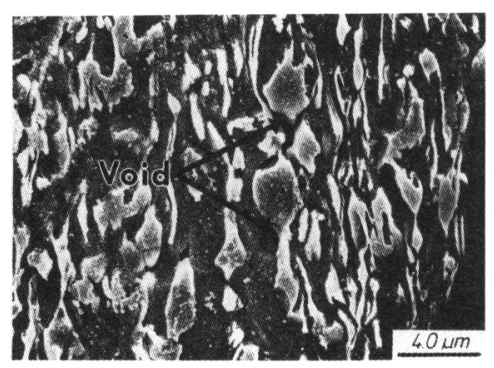

Fig.8.Scanning electron micrograph showing void formation and preferred particles orientation in necked portion of tensile specimen. Tensile direction is vertical to the micrograph.

なると考えられる。また，この種の鋼板の破壊は第 2 相と の界面から核生成したボイドが成長・合体して破断に至る ことが明らかである。

\section{$3 \cdot 3 \gamma_{\mathrm{R}}$ の変態過程}

$\gamma_{\mathrm{R}}$ 含む複合組織鋼板について，変形に伴う $\gamma_{\mathrm{R}}$ の変態過 程を調べるため, Fig. 2 に示した試験片を用いてTEMその 場変形実験を行った。T 3 鋼を用いて三つのタイプの $\gamma_{\mathrm{R}} に$ 対 して試みたが，フィルム状と島状の $\gamma_{\mathrm{R}}$ の変態過程は観察で きなかった。これらの $\gamma_{\mathrm{R}}$ は前述したように低ひずみ域では ほとんど変化しない。また薄膜試料を用いるTEMその場変 形では高ひずみ域までの実験が非常に困難である。

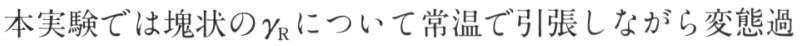
程を調べた結果, 下記の二つの変態経路があることを見出 した。

一つの経路は $\gamma_{\mathrm{R}}$ の双晶変形を経てマルテンサイトに変態 する場合で, 変形前後の組織をFig. 9 ( a ) と ( b ) に示す。変 形に伴う変態は瞬間的に起こるので連続写真を撮るのは非 常に困難であるが，電顕その場観察結果によるとべイナイ トと接しているフェライトから転位が動き出してそのフェ ライト粒の変形と同時に $\gamma_{\mathrm{R}}$ 粒との境界で堆積する。 $\gamma_{\mathrm{R}}$ 粒の 周りに堆積した転位は $\gamma_{\mathrm{R}}$ の双晶変形に必要な駆動力として 


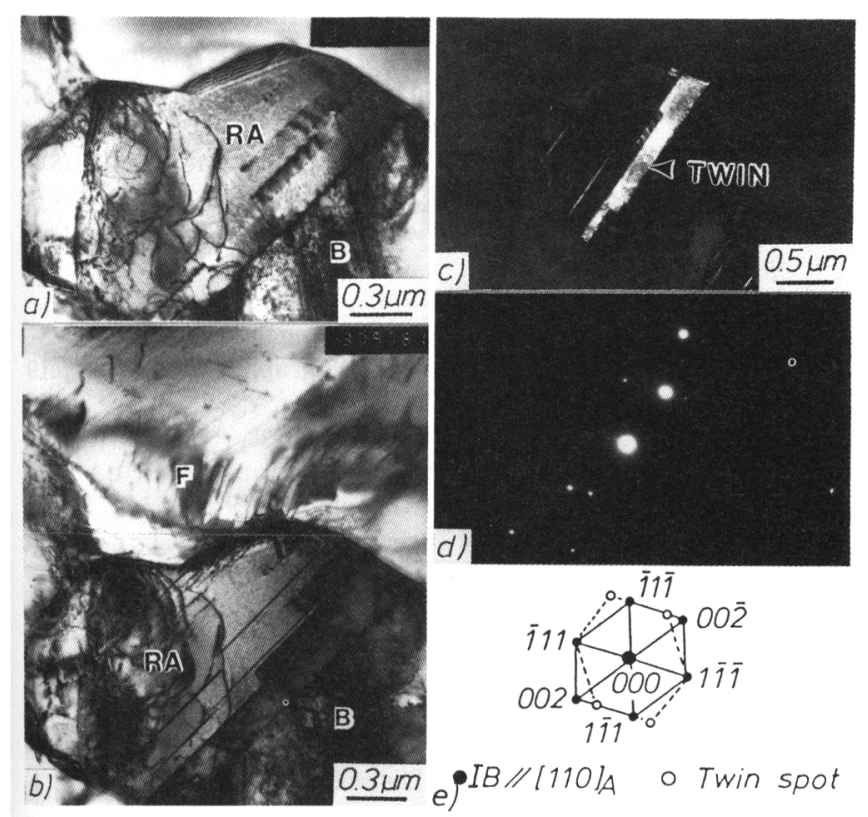

Fig.9.In-situ transmission electron micrographs showing strain induced $\gamma$-twin ; bright field images of (a) before and (b) after straining, (c) dark field image obtained from twin spot, (d) selected area diffraction pattern, and (e) indexed result of $(d)$.

作用して $\gamma_{\mathrm{R}}$ 粒内の欠陷部位 (Fig. 9 ( a )のヘリカル転位)から 双晶変形が起こる。Fig. 9 ( c ) の中の針状組織はをーマルテン サイトと非常に類似しているが，回折パターンから双晶で あることが確認された。また恋形量の異なる他の試料を用 いたX-線回折実験でもと-マルテンサイトは検出されなかっ た。このような双晶は変形量を増加させるより細い双晶の 発生と他の欠陥や双晶同士との交差部からマルテンサイト が生成する ${ }^{11)}$ 思われる。

もう一つの変態経路は $\gamma_{\mathrm{R}}$ から直ちにマルテンサイトへ変 態するもので, 変態前後の組織をFig.10に示す。この場合に も前と同様にまずフェライト領域から変形が起こりはじめ て隣接する $\gamma_{\mathrm{R}}$ 粒との境界に転位が堆積する。 $\gamma_{\mathrm{R}}$ 粒の周りに 堆積した転位のエネルギーがある臨界值超えると积は マルテンサイトに変態し得るが，この場合も $\gamma_{R}$ 粒内に存在 する積層欠陥が变態開始場所となる。

以上の結果から $\gamma_{\mathrm{R}}$ のマルテンサイト変態は $\gamma_{\mathrm{R}} \rightarrow \operatorname{twin} \rightarrow \alpha$, と $\gamma_{\mathrm{R}} \rightarrow \alpha^{\prime}$ 二つの経路があること胃出した。しかし， ぼ んな $\gamma_{\mathrm{R}}$ ぞの経路で変態するのかについては今後詳細な検 討が必要であ万うが，数回の観察を行った本実験の範囲で は次のように考えられる。塊状の $\gamma_{\mathrm{R}}$ はその内部に積層欠陷 を含むものと含まないものがある。積層欠陷を含む $\gamma_{\mathrm{R}}$ はそ の積層欠陷がマルテンサイトの核となって $\gamma_{\mathrm{R}} \rightarrow \alpha$ 'の経路で 変態するが $\left(\right.$ Fig.10), 積層欠陥を含まない $\gamma_{\mathrm{R}}$ は変形中に $\gamma$

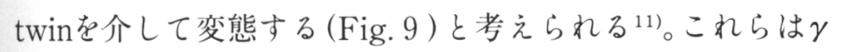
のマルテンサイト変態が剪断変形組織 $(\gamma$-twin, $\varepsilon$ 晶および すべりによる部分転位群)の交差部で核生成するという従来

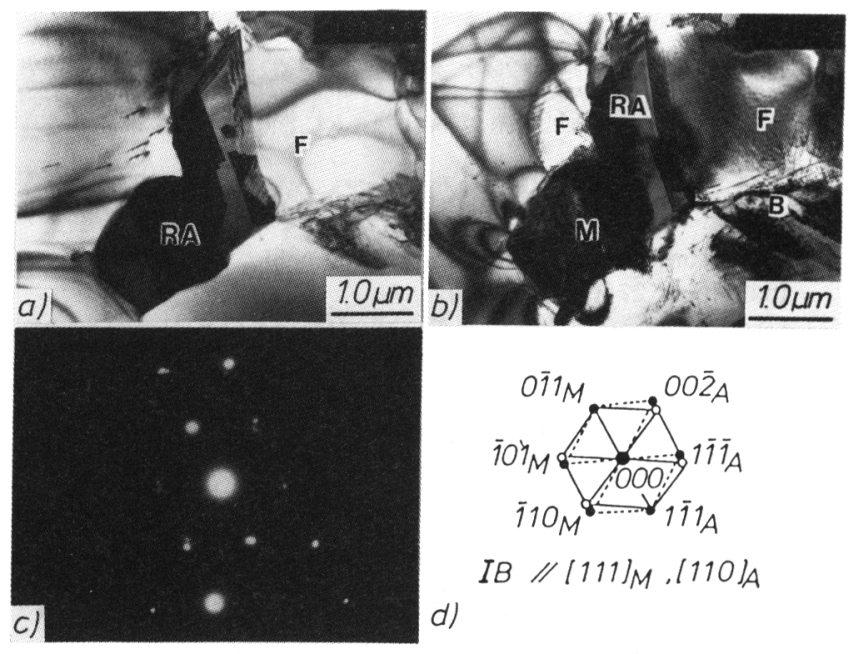

Fig.10.In-situ transmission electron micrographs showing strain induced martensitic transformation ; bright field images of (a) before and (b) after straining, (c) selected area diffraction pattern, and (d) indexed result of (c).

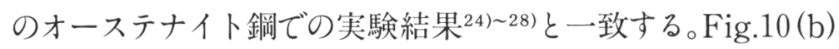
は $\gamma_{\mathrm{R}}$ の一部のみがマルテンサイトへ変態したもので, 変態 前後の結晶方位関係を確認することができる。Fig.10 (c)，(d) から $\gamma_{\mathrm{R}}$ と $\alpha^{\prime}-$ マルテンサイトとの結晶方位は (1111) $\gamma / /(01 \overline{1})$ $\alpha^{\prime},[110] \gamma / /[111] \alpha$ 'のKurdjumov-Sachsの関係を満たし ていることが確認された。

\section{4. 結言}

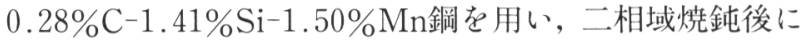
種々の温度にて恒温变態処理を施して鋼中の $\gamma_{\mathrm{R}}$ 量と形態を 変化させた。引張試験と電顕内その場变形実験を行い, $\gamma_{\mathrm{R}}$ を含导複合組織鋼板の变形と変態過程を調べて以下の結果 を得な。

（1） $\gamma_{\mathrm{R}}$ 量が多いほぼ鋼板の伸びは増加し, 強度〜延性バ ランスも優れる傾向であるが，同量の $\gamma_{\mathrm{R}}$ 含む場合でもそ の形態によって延性向上に寄与する度合が異なる。

( 2 ) $\gamma_{\mathrm{R}}$ の存在形態は三つのタイプに分類でき, フェライ 卜粒内に孤立している $1 \mu \mathrm{m}$ 以下の島状と硬質相の間に拘束 されているフィルム状は変形と変態を起こし難い反面, フ エライト粒界で形成されてべイナイトに接している $2 \mu \mathrm{m}$ 前 後の塊状は周りのフェライト粒の変形に伴って次第に変態 するものと考えられる。

( 3 ) TRIP型複合組織鋼板の変形過程は軟質のフェライト 粒の塑性変形, $\gamma_{\mathrm{R}}$ の変形双晶又はマルテンサイト変態, 硬 質相の一部の変形の順に起こり,この鋼板の破壊は第 2 相 との界面から核生成したボイドが成長・合体して破断に至 る。

( 4 ） $\gamma_{\mathrm{R}}$ のマルテンサイト変態は $\gamma_{\mathrm{R}} \rightarrow \mathrm{twin} \rightarrow \alpha^{\prime}$ と $\gamma_{\mathrm{R}} \rightarrow \alpha^{\prime}$ の 二つの経路があり， $\gamma_{\mathrm{R}}$ の内部に存在する積層欠陥の有無に 
よって変態経路が決まるものと考えられる。

( 5 ) $\gamma_{\mathrm{R}}$ と加工誘起マルテンサイトとの結晶方位はKurdjumov-Sachsの方位関係を満たす。

\section{文献}

1) O.Matsumura, Y.Sakuma and H.Takechi : Trans. Iron Steel Inst. Jpn., 27 (1987), p.570

2) I.Tsukatani, T.Kamei, S.Hashimoto and K.Hosomi : Microalloyed HSLA Steels, (1988), p.541 [ASM International, Chicago, Illinois]

3 ) Y.Sakuma, O.Matsumura and H.Takechi : Metall. Trans. A, 22 (1991), p.489

4 ) V.F.Zackay, E.R.Parker, D.Fahr and R.Bush : Trans. ASM, 60 (1967), p.252

5 ）松村 理, 佐久間康治, 武智 弘：鉄 と鋼, 77 (1991), p.1304

6 ）陳 煌泉, 友清憲治, 恵良秀則, 清水峯男 : 鉄 $＼mathrm{~ 鋼, ~ 75(1989), ~}$ p.626

7 ) 杉本公一, 翠 正宏, 小林光征, 白沢秀則：鉄 2 鋼, 76 (1990), p.1356

8 ) N.C.Goel, S.Sangal and K.Tangri : Metall. Trans. A, 16 (1985), p.2013

9 ) S.Sangal, N.C.Goel and K.Tangri : Metall. Trans. A, 16 (1985), p.2023

10）杉本公一, 小林光征, 臼井 登, 安木真一, 松島英浩: 材料 $と>^{\circ}$ ロセス, 3(1990), p.2012
11）片山哲也，藤田広志：日本金属学会誌， 52(1988), p.8

12）片山哲也，藤田広志：日本金属学会誌，52(1988)， p.935

13) T. Suzuki, H. Kojima, K. Suzuki, T. Hashimoto and M. Ichimura : Acta Metall., 25(1977), p.1151

14) K.Shimizu and Y.Tanaka : Trans. Jpn. Inst. Met., 19(1978), p. 685

15) A.Sato, H.Kasuga and T.Mori : Acta Metall., 28(1980), p.1223

16) L.Remy : Acta Metall., 26(1978), p.443

17) L.Remy and A.Pineau: Mater. Sci. Eng., 28(1980), p.99

18) B.V.N.Rao and M.S.Rashid: Metallography, 13(1983), p.19

19) R.L.Miller: Trans. ASM, $\mathbf{5 7}$ (1964), p.892

20) R.L.Miller: Trans. ASM, 61(1968), p.592

21) J.M.Rigsbee and P.J.Vander Arend: Formable HSLA and Dual Phase Steel, ed. by A.T.Davenport, (1979), p.56 [TMSAIME, New York]

22) A.F.Szewczyk and J.Gurland: Metall. Trans. A, 13A(1982), p. 1821

23) N.J.Kim and G.Thomas: Metall. Trans. A, 12A (1981), p. 483

24) J.A.Venables: Phil. Mag., 7(1962), p.35

25) R.Lagneborg: Acta Metall., 12(1964), p.823

26) P.L.Mangonon, Jr. and G.Thomas: Metall. Trans. A, 1 (1970), p.1577

27) F.Lecroisey and A.Pineau: Metall. Trans. A, 3(1972), p.387

28) G.B.Olson and M.Cohen: Metall. Trans. A, 6(1975), p.791 